\title{
Professionalism Development of High School Teachers in Improving the Ability to Implement Realistic Mathematics Education in East OKU Regency
}

\author{
Edwar Edwar ${ }^{1, *}$ Ratu I. I. Puteri ${ }^{1,}$ Zulkardi Zulkardi ${ }^{1}$
}

\author{
${ }^{1}$ Department of mathematics Education, Universitas Sriwijaya, Indonesia \\ *Corresponding author.Email: edwaryanto@yahoo.com
}

\begin{abstract}
The results of the teacher competency survey from the 2018 Program for International Student Assessment (PISA) put Indonesia in rank 74 out of 79 . This shows the low quality of teachers that has an impact on student achievement. The ability of students is very lacking, especially in the ability of understanding, reasoning, and solving mathematical problems. Therefore, a teacher as the main designer in the learning process is required to be able to master learning theory and learning principles and be able to master and develop learning materials creatively. The principles and creative learning materials are known as realistic learning models. Therefore, this study aims to improve the competence of high school teachers (particularly in the East OKU district) in implementing realistic mathematics education (RME). This research method is divided into three stages, namely: First Stage: socialization in the form of lectures and discussions about RME material. The second stage: workshop/training/assistance in program preparation, and preparation of teaching materials using RME. The third stage: the implementation of learning in schools, along with the monitoring system. The results of the analysis conclude that this study has increased the professional competence of teachers in implementing realistic mathematics learning as indicated by its potential influence on student learning outcomes (the average score of students' abilities is 70.16). The average value of the results of observing student activities during learning is 3.09 .
\end{abstract}

Keywords: RME, Teacher professional development, High School Teacher, Development.

\section{INTRODUCTION}

The results of the 2018 PISA survey put Indonesia in 74th place out of 79 countries, while the results of the Organization for Economic Co-operation and Development (OECD) survey in mathematics put Indonesia in 7 th place from the bottom with a score of 379 (OECD average - 489) [1]. The questions issued in PISA and OECD are questions that require thinking and analytical skills that allow children to have analytical competence, think critically, solve problems, increase creativity, and generate innovation. This shows that students' analytical skills in Indonesia are very poor. The cause of low student learning outcomes in learning mathematics cannot be separated from the learning process, namely the approach or learning model used by the teacher in delivering the material [2]. Students do not understand the material given by the teacher because the students' mindset is still concrete while the teacher already knows the students' mathematical concepts. Learning mathematics begins with the concrete (real), after arriving at the abstract (the introduction of mathematical concepts). For that, we need a learning method that can improve education, especially in the ability to understand, reason with quality, and solve mathematical problems. The appropriate learning approach is Realistic Mathematical Education (RME) where this mathematics learning approach is oriented to the mathematization of everyday experiences and the application of mathematics in everyday life or can be imagined by students [3]. By presenting the material presented in accordance with the intellectuality of students and the surrounding subject matter, it can help students to make it easier for students to understand the mathematical concepts being taught and facilitate learning mathematics. Therefore, a teacher as the main designer in the learning process must be able to master learning theory and learning principles and be able to 
master and develop material in this case RME. However, in the teaching and learning process, it turns out that many teachers do not understand realistic mathematical concepts. Based on preliminary research, it shows that $20 \%$ of 35 mathematics teachers in the East OKU district are not familiar with the concept of realistic mathematics learning and $54.3 \%$ of 35 mathematics teachers in the East OKU district have not been able to master the learning principles of developing RME in learning.

Therefore, this study aims to improve the competence of secondary school teachers (particularly in the East OKU area) in implementing realistic mathematics education (RME).

\section{METHODS}

\subsection{Research Subject}

Research subjects were 35 high school math teachers in the east oku area who were members of the mgmp. The research was carried out in january of 2019. This research is a developmental research offering workshops for teachers to improve the proficiency of secondary school teachers (especially in the east OKU area) in implementing realistic math education.

\subsection{Research Methods}

This research method is divided into three stages (figure 1), namely: First Stage: socialization in the form of lectures and discussions about RME material. The second stage: workshops/training/assistance in program preparation, and preparation of teaching materials using RME. The third stage: implementation of RME teaching material in schools. In this third stage, the researcher uses the development method which includes several stages, namely preliminary and formative evaluation and field test $[4,5]$.

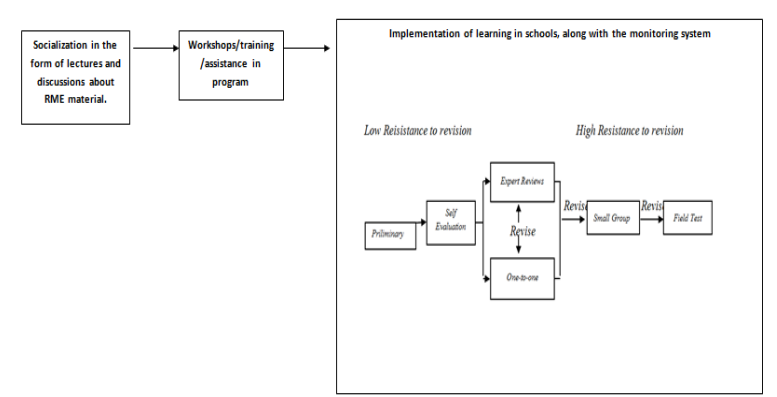

Figure 1 Research design flow

\subsubsection{Socialization}

Socialization in the form of lectures and discussions was conducted by experts, namely Prof. Ratu Ilma Indra Puteri and Prof. Zulkardi from Sriwijaya University.

\subsubsection{Workshops}

Workshops/training/assistance in program preparation and preparation of teaching materials using RME were conducted by experts, namely Prof. Ratu Ilma Indra Puteri and Prof. Zulkardi from Sriwijaya University.

\subsubsection{Development Method}

The development research method is not much different from other research approaches. However, the development research focused on 2 stages, namely the preliminary stage and the formative evaluation stage. The following will be described in detail [5].

\subsubsection{Preliminary}

Preliminary consists of the analysis stage and the design stage. In the stage analysis, researchers analyzed the results of initial research on teacher competence in developing RME-based teaching materials. At the design stage, the researcher determines the place and subject of the research, designs the research schedule, and establishes cooperation with related parties.

\subsubsection{Self-evaluation}

Self-evaluation is the stage where researchers design their products to be developed, which in this case are RME teaching material $[4,5]$.

\subsubsection{3. .Expert Review And One-To-One.}

The prototype in this study was divided into 3 stages, namely the first prototype, the second prototype, and the third prototype as the final prototype (product). Each prototype is validated by experts based on characteristics (content, constructs, and language) $[7,8,9,10,11]$. Experts are also required to provide suggestions for revising teaching materials based on the characteristics (content, constructs, and language) of each prototype.

\subsubsection{Small group}

RME teaching materials that have been developed are tested first on a small group of students to see the practicality of the teaching materials $[4,5]$. 


\subsubsection{Field test}

The product of teaching materials that have been tested on a small group of students is revised so that it has three quality criteria, namely validity, practicality, and benefit $[4,5]$. Teaching materials were tested on high school students (SMA) in East OKU District who were the subjects of the study.

\subsubsection{Data Analysis Technique}

This study uses descriptive analysis in developing RME teaching materials by following the directions and recommendations of experts so that the materials produced are valid and practical. In addition, RME teaching materials were also developed from the results of small group assessments of students by paying attention to small group activities in teaching and learning activities using RME teaching materials [4,5].

\subsubsection{Analysis of Student Activity Observation Data}

Observations were made to determine student activities in the teaching and learning process. Observations were carried out by two observers to observe student activities in learning. Aspects observed by observers must be in accordance with the Learning Implementation Plan [4,5].

\section{RESULT AND DISCUSSION}

The workshop held at the East OKU MGMP to develop teacher professionalism and competence can be said to be successful. This is in accordance with research by Annisa (2019) and Edward (2021) which state that training can improve teacher knowledge and skills [6]. The development of teacher professionalism and competence in this study has a positive impact on teachers because it increases teacher competence in preparing RME teaching materials. This is indicated by data analysis and expert opinion that the RME teaching material made by the participant from this research is categorized as valid and practical and also has a potential influence. This can be demonstrated by materials created by participants that demonstrate their validity, practicality, and potentialeffect.

\subsection{Validity}

This study produced three types of prototypes, namely the first, second, and third prototypes. The first prototype was made after the teacher attended a workshop which was then validated by an expert who would produce a second prototype by considering the advice of experts on the first prototype. The second prototype was tested on a small group of students and re-validated by experts who would then produce a third prototype. The third prototype was obtained by taking into account the expert's suggestions for the second prototype and by analyzing the result of observing student activities in small groups. Validity is assessed by experts based on the validity of the content, construct, and language. In this study, the expert stated that the RME teaching produced had content validity because it was in accordance with the curriculum, the RME teaching materials produced also had construct validation indicated by the teaching material that was able to measure every aspect of the learning objectives, these teaching materials also had language validity because it does not cause multiple interpretations.

\subsection{Practical}

The RME teaching materials produced by the workshop participants can be categorized as practical because the practicality of RME teaching materials is measured by the ease of using teaching materials $[6,12]$. The resulting RME teaching materials were said to be practical by experts in the second prototype and tested in small groups. The results of the experimental observation of RME teaching materials in small groups showed that students were enthusiastic and happy to do every given activity because it was equipped with interesting pictures and RME teaching materials related to their daily activities so that they felt mathematics was useful in each of their activities.

\subsection{Potential}

The workshop on teacher professional development in developing teaching materials was attended by 35 high school teachers as participants. Participants who stated that this workshop was very useful were $100 \%$, meaning that this workshop was very useful for increasing their ability to develop teaching materials. As many as $88.2 \%$ of participants stated that after attending this workshop they were able to develop RME-based teaching materials but $94.1 \%$ of participants still found it difficult to develop RME-based teaching materials so they hoped that a follow-up workshop would be held to improve their abilities (Table 1).

Table 1. Workshop participant testimonial

\begin{tabular}{|c|c|c|}
\hline \multicolumn{3}{|c|}{ Testimonial } \\
\hline Useful & $\begin{array}{l}\text { Has developed RME } \\
\text { teaching material }\end{array}$ & $\begin{array}{l}\text { Difficulties in } \\
\text { developing RME } \\
\text { teaching } \\
\text { material }\end{array}$ \\
\hline $100 \%$ & $88,2 \%$ & $94.1 \%$ \\
\hline
\end{tabular}

The third prototype which has been declared valid and practical by experts was tested in 5 (five) schools, namely SMA N 1 Martapura, SMA N 2 Martapura, 
SMA Negeri 3 Martapura, SMA Muhammadiyah Martapura, and SMA YIS, and the average score of students was 70, 16 which are based on the learning outcomes category are included in the sufficient category (Table 2).

One of the results that we can see directly from the implementation of the teacher professional development workshop in developing RME-based teaching materials is student learning outcomes. Student learning outcomes showed significant results (significantly different because t-test $>\mathrm{t}$ table) after being tested statistically using the SPSS program with paired t-test. Student learning outcomes also show that $70 \%$ of students have sufficient grades so that the teacher professional development workshop in developing teaching materials This RME-based approach is said to have a potential effect. The results of the analysis of observations made by two observers showed that the average student activity was 3.09 (Table 3 )

Table 2. Percentage of student value

\begin{tabular}{|l|l|l|l|l|l|}
\hline \multirow{2}{*}{ NO } & \multirow{2}{*}{ Name school } & \multicolumn{4}{l|}{ Percentage (\%) } \\
\cline { 3 - 6 } & & $\mathrm{A}$ & $\mathrm{B}$ & $\mathrm{C}$ & $\mathrm{D}$ \\
\hline 1 & $\begin{array}{l}\text { SMAN 1 } \\
\text { Martapura }\end{array}$ & 10,00 & 13,33 & 60,00 & 16,67 \\
\hline 2 & $\begin{array}{l}\text { SMAN } \\
\text { Martapura }\end{array}$ & 5,55 & 16,67 & 55,55 & 22,22 \\
\hline 3 & $\begin{array}{l}\text { SMAN } \\
\text { Martapura }\end{array}$ & 18,75 & 25,00 & 43,75 & 12,25 \\
\hline 4 & $\begin{array}{l}\text { SMA } \\
\text { Muhamadiya } \\
\text { h Martapura }\end{array}$ & 0.00 & 6,25 & 18,75 & 75,00 \\
\hline 5 & $\begin{array}{l}\text { SMA YIS } \\
\text { Martapura }\end{array}$ & 9,09 & 0,00 & 18,18 & 72,72 \\
\hline
\end{tabular}

Note: $\quad \mathrm{A}($ Excellent $)=86$ s.d $100 \mathrm{~B}(\mathrm{Good})=71$ s.d 85 $\mathrm{C}($ Fair $)=56$ s.d $70 \quad \mathrm{D}($ Poor $)=0$ s.d 55

\section{CONCLUSION}

The result of this research shows that teachers This study shows results that workshops can improve the professionalism and development of teacher competencies in developing RME-based teaching materials. The results of this study showed that the participants were able to make materials based on RME which were categorized as valid and practical. The results of this study also show that the increase in teacher competence affects the average value of students' abilities by 70.16 and the ability of teachers to develop RME-based teaching materials also affects student activities, namely an average of 3.09 indicators that appear in each activity.

\section{AUTHORS' CONTRIBUTIONS}

This research is useful to improve the professionalism and competence of teachers in developing RME-based teaching materials. This research is also useful for improving students' ability to think logically and quickly.

\section{ACKNOWLEDGMENTS}

The researcher is happy to thank Sriwijaya University through the doctoral program in mathematics education which allowed the researcher to be able to complete his research and thank you to the Chairman of MGMP of East OKU Regency, Chairman of SMA N 1 Martapura, Chairman of SMA N 2 Martapura, Chairman of SMA N 3 Martapura, Chairman of SMA Muhammadiyah Martapura, Chairman of SMA-YIS Martapura, and High School Teachers in East OKU Regency.

\section{REFERENCES}

[1] OECD, "What is PISA?". PISA 2018 Assessment and Analytical Framework, OECD Publishing,

Table 3. ObservationalResults in Student Activities

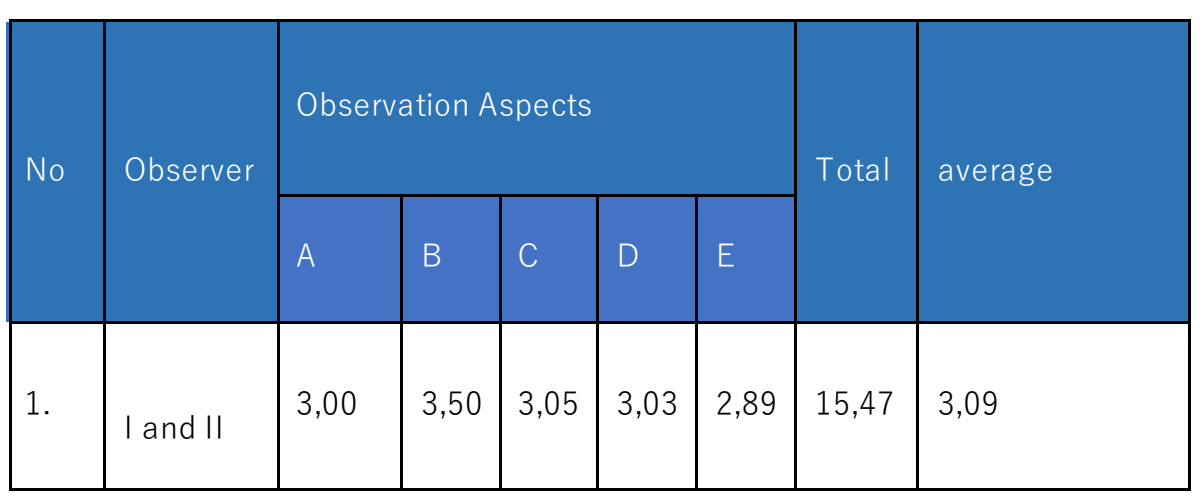


[2] H. Ipi, Penerapan pembelajaran matematika realistik indonesia (pmri) untuk meningkatkan hasil belajar matematika siswa kelas 1sd Negeri 011 Bukit Gajah Kecamatan Ukui Kabupaten Pelalawan, in Primary Program Studi Pendidikan Guru Sekolah Dasar Fakultas Keguruan dan Ilmu Pendidikan Universitas Riau, vol. 5, pp 451-471, 2016.

[3] Suryanto, et al., Sejarah PendidikanMatematika Realistik Indonesia (PMRI). Ditjen Dikti Kemendiknas, 2010.

[4] T. Martin, Conducting formative evaluations, Kogan page, 1993.

[5] Zulkardi, R. Ilma, Mendesain sendiri soal kontekstual matematika. Prosiding Konferensi Nasional matematika XIII: Matematika dan Aplikasinya: 30 Tahun Himpunan Matematika Indonesia, Semarang, Badan Penerbit Universitas Diponegoro, 2006. DOI: http://:www.PMR.or.id

[6] M. Annisa, A. Nanna, A. Sofyan, D. Kusnadi, Pengembangan Profesionalisme Guru Melalui Pelatihan Pengembangan Tes, Konstruksi Dan Analisis Butir Soal Di Wilayah 2T, J. Pendidikan IPA 9(2) (2019) 46-51. DOI: https://doi.org/10.24929/lensa.v9i2.63

[7] S. Haynes, D. Richard, E. Kubany, Content Validity in Psychological Assessment: A Functional Approach to Concepts and Methods. Psychological Assessment 7(3) 238-247 (1995). DOI: $\quad$ https://psycnet.apa.org/doi/10.1037/1040$\underline{3590.7 .3 .238}$

[8] S. Mesick, Ethnocultural Issues in the assessment. Validity. In R. Linn, 1993.

[9] K.R Murphy, C.O Davidshofer, Psychological Testing: Principles and Applications, Prentice-Hall, 1991.

[10] S.Suryabrata, Pengembangan Alat Ukur Psikologis, Penerbit Andi, 2005.

[11]Sugiyono. Metode Penelitian Pendidikan Pendekatan Kuantitatif, kualitatif, dan R\&D. Alfabeta, 2010.

[12] Mustofa, Pengembangan Profesionalisme Guru di Indonesia, J. Ekonomi \& Pendidikan. 4 (1) (2007) 76-88. DOI https://media.neliti.com/media/publications/17245ID-upaya-pengembangan-profesiona lisme-guru-diindonesia.pdf 